\title{
Historical Writing of the Battle of Sarhu and the Imperial Propaganda of Qianlong
}

\author{
WANG Chuan \\ The Museum of the Imperial Palace of “Manchukuo”, Chang Chun, China
}

\begin{abstract}
The Battle of Sarhu, a series of battles between the Late Jin Dynasty (later known as the Qing Dynasty) and the Ming Dynasty in 1619, was described as a symbol for the rising of the Late Jin Dynasty by the historical narratives of Qing Dynasty. But indifferent Qing Dynasty emperors’ historical narratives about the Battle of Sarhu, they had different emphases on their narratives. By comparing the historical narratives of the Qing TaiZu Huang Di Shi Lu and Kang Xi’s historical narrative the Qing Tai ZuGao Huang Di Shi Lu, the paper explores Qianlong's political appeal for protecting legitimacy and ordering the monarch-subject relationship, as well as cautioning to the Eight Banners through the text selection, text structure, and the text content of Sarhu Zhi Zhan Shu Shi.
\end{abstract}

Keywords: Qianlong, the Battle of Sarhu, historical narratives

Moral legitimacy is a significant principle of political ethic in the ancients' ideology. In the imperial times, the highest legitimacy is the orthodox of dynasties. Whether the rulers' dominance is legitimate or not directly influences the public's judgment on the legitimacy of the rulers and their successors. However, not all empire successors are immune from this challenge, and it is difficult for their ancestors to obtain political power in a completely proper way. So, the orthodox-problem is like the sword of Damocles hanging over the heads of imperial rulers. Once the people have doubts about their dominance, the empire is likely to fall into the chaos because of the problem of right of inheritance. The Qing Dynasty, which was established by the Manchus, seems to be particularly troublesome on this issue. Because its founders, originally lived in the northeast fringe of the Ming Empire, had once submitted itself to the latter's rule which they at last overthrew. The act of infidelity and injustice is judged as the head of the "Ten unforgivable crimes" (Da Qing Lï Li, Volume 1, 1986, p. 408) in the ancient Chinese law, and will be subjected to the most severe punishment. In order to solve "the dilemma of Manchu’s success” (Elliott, 2014, pp. 70-98), the successors of Qing Dynasty, represented by Emperor Qianlong, carried out a series of imperial propaganda. Sarhu Zhi Zhan Shu Shi is a representative of those imperial propaganda.

\section{The Battle of Sarhu and the Sarhu Zhi Zhan Shu Shi}

Qing Dynasty was the last dynasty in Chinese imperial history. It was founded by Nurhachi, the leader of the Jurchen of Jianzhou State in the Late Ming Dynasty. Jianzhou Jurchen is a vassal state of the Ming Dynasty in the

WANG Chuan, The Museum of the Imperial Palace of “Manchukuo”, Chang Chun, China. 
northeastern frontier, and every chief of this tribe must accept the government post bestowed by central government in order to get recognized. Meanwhile, this sort of marginal but inseparable tribes are controlled by tribute trade and strong military suppression from the central government.

Nurhachi's grandfather and father were "killed by mistake” (Ming Shen Zong Shi Lu, Volume 569, 1962, p. 10704) by the Ming army in a military conflict, and this caused the conflict between Nurhachi and the Ming Dynasty. Although the Ming Dynasty appeased him, Nurhachi apparently complained about the bizarre death of his father and the Ming Dynasty's "unfairness" to the Jurchen tribes. In 1616, Nurhachi released the "Seven Hatreds" and began the war against the Ming Dynasty. The northeastern frontier was lost; in Beijing, Wanli Emperor clearly felt the crisis. In order to defend the dignity of "Son of Heaven", military reactions was taken, which finally led to the Battle of Sarhu.

In 1618, Wanli Emperor mobilized an army of nearly 100,000 men and divided it into four groups to attack the "capital city" of the Late Jin Dynasty. However, the war ended with a victory of Nurhachi, whose resource was inferior to the Ming Dynasty in all respects. Right after the Battle of Sarhu, Nurhachi and his successors occupied the entire western Liaoning region in just the five years. This achievement can be said to have avenged the killing of his father. 23 years later, Jurchen occupied Beijing and became the master of the Chinese Central Plain and completely replaced the Ming Empire. Finally, the unification was realized by Kangxi Emperor.

In order to commemorate the decisive battle (i.e., the Battle of Sarhu) between Ming Dynasty and Qing Dynasty, Nurhachi's successors continuously compiled history books and held sacrifices. The first record of the Battle of Sarhu was conducted by Nurhachi's son Huang Taiji. In 1636, he compiled a four-volume book Tai Zu Wu Huang Di Shi Lu, which imitated Han chronicle tradition of Han People to describe his father's founding merits.

In order to highlight the glory of his great-grandfather, Emperor KangXi revised the Tai $Z u W u H u a n g ~ D i$ Shi Lu and renamed it Tai Zu Gao Huang Di Shi Lu. Emperor Qianlong's ShuShi can be viewed as the third recollection of the Qing emperors' records to the Battle of Sarhu. To such an emperor who craved for greatness and success, it seemed that it was not enough to eulogize his ancestors just in the form of words. So he took a more intuitive approach: to erect a monument for Nurhachi in the ancient battlefield. On this monument, he engraved his own reminiscences, which is the origin of the Monument of the Battle of Sarhu (Liaoning Bei Zhi, 2002, p. 170) ${ }^{1}$ and ShuShi. Now the monument is in Shenyang Palace Museum. We believe there are different political considerations between Qianlong Emperor and the former emperors behind this unique commemorative approach.

\section{The Imperial Propaganda of Qianlong Emperor}

Through a comparison of the ShuShi, the Tai Zu Wu Huang Di Shi Lu, and the Tai Zu Gao Huang Di Shi Lu, it is not difficult to find that there are obvious changes in literary form, article structure, and text content in ShuShi.

\footnotetext{
${ }^{1}$ Engraved in the 41th year of Qianlong (1776). In Bluestone, 2.4 meters high, 2.15 meters wide, and 32 centimeters thick. On the front of the tablet is engraved with the Shushi, which is the writing of Qianlong. It contains 94 lines of Chinese character, with a total of more than 6,000 words. The back side is engraved with 93 lines of text. The content is the same as that of the front side. The right side of the tablet is engraved with a seven-character poem written by Jiaqing Emperor, a total of 16 sentences. The monument was originally located at the hillside of Sarhu Mountain in Fushun. It was moved to the Shenyang Palace Museum in 1978 due to the construction of the Dahuofang Reservoir.
} 
Through the analysis of these changes, we can see the implications behind Qianlong's ShuShi.

Let us start with the literary form of the ShuShi. Although this chronology has been regarded by the ancient Chinese as one of the most serious historical records, the style chosen by Qianlong in the reminiscence is different from the genre used by Kuang Xi and Huang Taiji. Monarchical records are usually hidden in the palace, not known to outsiders because they have the function of recording the deeds of the former emperors and providing reference to the latecomers (Feng, 2004, p. 33). As a result, Qianlong Emperor commemorated the glory of his ancestors by erecting a monument on Sarhu mountain. The reason he did not use annalistic style is that focusing onthis whole events can describe its complete process better. This style is more readable than the inconsistent recording method of annals, and is more conducive to expressing the author's thoughts. Since ancient times, the Chinese people have had the habit of searching for historical sites. Apparently, it is more propagandistic to erect the monument on the ancient battlefield to make passersby mourn the great emperor.

Then, article structure. Comparing the ShuShi with the Tai Zu Wu Huang Di Shi Lu and the Tai Zu Gao Huang Di Shi Lu, the most crucial difference is the lengthy praise taken in the Shushi (Gao Zong Chun Emperor Shi Lu/Qing Shi Lu: Book 21, 1986, p. 316). ${ }^{2}$ Ancient Chinese historical witting emphasizes that historical records should have the function of warning others. After finishing their works, historiographers would comment the contents according to their own cognition. The standard of such comments is mostly based on moral principle and personal feelings, and it became the value judgment of historiographers, such as Tai Shi Gong Yue in the Shi $J i$. The previous war descriptions only made a record ofthatbattle, and did not rise to the level of historical introspection and comment. Therefore, it did not contain any historical comment. The intentions of Qianlong Emperor's latter-added harangue are as follows. Firstly, it emphasizes that the Qing Dynasty's replacement of Ming was "the will of Heaven", and marks the moral authority of the orthodox position of the Qing Dynasty. People is the foundation of "the will of Heaven", which means "propitious reward comes from the God; the reward of regime comes from people". "People" here refers to "the father, the sons, the emperor, and the ministers"- "the father" and "the emperor" refer to the laborious founding emperor Nurhachi. "The sons" and "the ministers" refer to the ministers and relatives who helped to found Qing Dynasty. Secondly, through the analysis of above, we can glimpse the wish of Qianlong on constructing the ideal relationship between the monarch and the ministers. The tradition offorest-hunting has a profound impact on the politics of Jurchen. Nurhachi even built a military democratic system before his death. This is a decision-making committee composed of his four sons and the Eight Qi leaders, replacing the tradition of autocratic monarchy of Han People. As a result, in that period, the relationship between the monarch and the minister stresses on individual initiative. Under this precondition, the monarch, the Beile (princes), the Qi leaders, and ministers would try their best to cooperate with each other for the common interests. However, with the aim of establishing the great unification, Qing Emperor cannot insist on such a primitive approach to manage a huge empire. So he decided to adopt the former institution of Ming Dynasty. He emphasized the ministers' dedication and contribution (Gao Zong Chun Emperor Shi Lu/Qing Shi Lu: Book 21, 1986, p. 317), which means their absolute obedience of to the monarch, which can be reflected in the comparison of later texts.

\footnotetext{
2 The original text is in: Gao Zong Chun Emperor Shi Lu/Qing Shi Lu: Book 21. Beijing, 1986, p. 316.
} 
Finally, text content. We can understand the general intention of Emperor Qianlong's writing from the comparison of literary form and article structure. Furthermore, we can substantiate these abstracted views and intentions from the brief and obscure ancient Chinese words through a careful content comparison.

The description of the causes of war and the details of the battlefield. There is no general account of the reasons of the war in Shushi. This phenomenon does not exist in the previous records, and it does not meet the structural requirements. Besides, the details of the battlefield narrated in Shushi is more elegant. The bloody battle scene does not appear too much in it. Instead, it rather strengthens the scene of Manchurian soldiers obeying command, their virtue of strict military discipline, heroic combat, and their excellent riding and shooting skills. For instance, in the battle of reinforcing Jiefan mountain, Huang Taiji advised his big brother to change the strategy of ambush to active combat. In the Shushi, it deliberately stresses this action as "bravely facing the enemy” (Gao Zong Chun Emperor Shi Lu/Qing Shi Lu: Book 21, 1986, p. 319), while previous version describes this as "standing in front of the enemy". These two versions achieve two completely different effects. Qianlong's version has a political implication by stressing ancient Eight Banners army's courage to set a good example for the present one. And that is because in mid-times of Qianlong, the fighting capacity of Baqi army has declined. In the descriptions of the Jurchen generals, Qianlong's intentions seems to be more concealed. And the following two records are worth pondering. On the first day of March, 1618, scout reported that Ming army had had arrived. In the Tai $\mathrm{Zu} W u$ Huang Di Shi $L u$, it says: "all the princes gathered in the court and reported the message to Nurhachi”. And the latter two versions just simply recorded Nurhachi's command. Similar detailed choice reflected in the description of the final battle with Liu Ting. The latter two versions record it in this way: Following up a victory, Huang Taiji pursuit eagerly, and met Liu Ting's two battalions. However, the original record in the Tai $Z u W u$ Huang Di Shi $L u$ is that not only Huang Taiji, but also three other brothers met head-on Ming army. Whereafter, Shushi has the record of four brothers chasing Ming army, which is inconsistent with the previous records. Maybe there are two purposes in Qianlong' version: firstly, emphasizing the merits of Huang Taiji, the successor of Nurhachi and decentralizing his great brother Dai Shan who was more competitive to the throne in that period, as well as focusing on his own legitimacy of inheriting the throne; secondly, to express the appeal of establishing a new relationship between the monarch and the minister. For example, he neglected the plot of "Feudal Princes discussing together" to strengthen the image of Nurhachi as a decision-maker. And the reason for the victory of the war is attributed to "not only the hard work of the ancestors, but ministers who worked together at the time" (Gao Zong Chun Emperor Shi Lu/Qing Shi Lu: Book 21, 1986, p. 324). The strengthening of the image of Huang Taiji and the weakening of that of Dai Shan actually emphasize a kind of relationship between the monarch and the minister, that is, the absolute obedience of the courtier to the monarch.

\section{Conclusion}

Since the 40th year of Qianlong, the emperor seemed to encounter a "crisis of orthodoxy". Qianlong continued to master the power of historical compilation and promoted the rebuilding of the founding history through the Shushi. And this book created the official memory of the Battle of Sarhu for the descendants. Absolutely, Qianlong's writing of the Shushi is not an occasional decision. Through Qianlong's years of personal visits to the site of Sarhu and his poems, we can see his concern for the Battle of Sarhu. The rewriting of that battle was actually to create glory of his ancestors. Through the records of the glory and remembrance, he tries to 
strength the authority of his rule and then to educate his ministers and future generations that they shall never forget the difficulties of the founding of the Qing Dynasty, which their ancestors had devoted to.

\section{References}

Da Qing Lù Li, Volume 1. (1986). The 670th volume of the History Department of Jing Yin Wen Yuan Ge Si Ku Quan Shu. Taipei: Commercial Press.

Elliott, M. C. (2014). Emperor Qianlong. Beijing: Social Sciences Academic Press.

Feng, E. K. (2004). Study of Qing Dynasty historical source. Shenyang: Shenyang Publishing House.

Gao Zong Chun Emperor Shi Lu/Qing Shi Lu: Book 21. (1986). Beijing: Zhonghua Book Company.

Liaoning Bei Zhi. (2002). Shenyang: Liaoning People's Publishing House.

Ming Shen Zong Shi Lu, Volume 569. (1962). Taipei: The Institute of History and Philology Academia Sinica in Taiwan. 